\title{
Effects of Work Motivation as Variables Intervening Between Autocratic Leadership and Transformational Leadership on Employee Performance in Family Business (Study at PT. Andalan Medika Sejahtera Abadi)
}

\author{
Aisyah Wida Sari \\ PT. Andalan Medika Sejahtera Anadi \\ aisyahwidasari@gmail.com \\ https://doi.org/10.37715/rmbe.v1i2.2437
}

\begin{abstract}
Leadership is an important aspect of an organization or company. The purpose of this study was to measure the effect of work motivation as an intervening variable between autocratic leadership and transformational leadership on employee performance in the family business (study at PT. Andalan Medika Sejahtera Abadi). Respondents in this study were 55 people, all of whom were employees of PT. Andalan Medika Sejahtera Abadi, using quantitative methods and path analysis. In this study, it was found that all variables have a significant and positive effect. However, the relationship between autocratic leadership and motivation has a higher value. The results of this study are unique because they use different subjects from previous studies, namely family business companies.
\end{abstract}

Keywords - Autocratic Leadership, Transformational Leadership, Family Business, Work Motivation, Staff Performance.

\section{Introduction}

PT. Andalan Medika Sejahtera Abadi is a distributor of medical devices, especially implants and orthopedic instruments, is the sole distributor of PT. Eka Ormed Indonesia is engaged in manufacturing medical devices with a focus on the production of implants and orthopedic instruments. Indonesia is an archipelagic country with 34 provinces and each city or district almost always has a minimum of 1 State Hospital. In 2012-2018 there was an increase in the number of hospitals in Indonesia. So that PT. Andalan Medika Sejahtera Abadi is committed to always developing in the healthcare industry, by collaborating with several hospitals in Indonesia. The increasing collaboration between PT. AMSA with several hospitals in Indonesia, the burden number of jobs accepted by Human Resources (HR) will increase.. In addition, the company also has several offices representatives so that the number of human resources in the company is also increasing increase.

\section{Literature Review}

2.1. Previous Research

Research (Husein et al., 2018), explains that organizational culture affects motivation and has a positive impact on student achievement at the Daaruttaqwa Islamic Boarding School Cibinong Bogor. Research (Noor et al., 2018) shows that a less conducive organizational culture is caused by members who only wait for instructions from the leadership resulting in administrator-style leadership of the head of the room. While the implementation of the strategic plan depends on how the workforce in the hospital runs it, especially how the leadership is.

Research (Sendjaya et al., 2008) shows that it is important to have a good relationship between leaders and employees, by showing creativity and innovation. The servant leadership approach is able to encourage creativity not only in European-American culture but also in Asia. As well as the importance of building psychological relationships with employees to enforce employee creativity and team innovation.

Research (Sarmawa et al., 2017) shows the results that work culture has a significant effect on selfleadership which has an impact on employee performance. Because with the ability of oneself, a person will be able to lead himself to reach the goals that have been set. Research (Ziyae \& Heydari, 2016) shows the results that there is an insignificant and positive relationship between strategic behavior, natural reward strategies, constructive thinking patterns and entrepreneurship in developing their own abilities. Because an entrepreneur can train his workforce to improve their own leadership skills and thus their ability to innovate even more. So, based on some of 
the opinions of the research above, it shows that there is self-leadership which has a very significant effect and some does not significantly affect the job satisfaction of company employees.

Research (Veriyani \& Prasetio, 2018) says that compensation has a significantly positive effect on job satisfaction, which means that the compensation provided by PT. Soljer Abadi is good and can increase job satisfaction. According to research (Warrick, 2017), developing organizational culture also requires more than just talking about culture and work emphasis. To achieve the best results, cultural development requires leaders who see it as one of their main tasks and who understand their work. So, according to some of the studies above, compensation is very influential in employee performance satisfaction.

\subsection{Theoretical basis}

\subsubsection{Job satisfaction}

According to Luthans (2007, as cited in Changgriawan, 2017), job satisfaction is a positive feeling that is formed from an employee's assessment of his work based on the employee's perception of how well his job is, which means that what is obtained at work has fulfilled what is considered important. According to Frederick Herzberg in research Andriani and Widiawati (2017), suggests that everyone in carrying out their work is influenced by two factors which are needs, namely:

1) Hygiene factors: Hygiene Factors or Dissatisfiers are factors that become a source of dissatisfaction consisting of salary/wages, supervision, interpersonal relationships, working conditions and status. If these factors are not met, employees will not be satisfied. However, if the magnitude of this factor is sufficient to meet these needs, employees will not be disappointed even if they are not satisfied. According to Frederick Herzberg (1959), what can spur people to work well and create a passion for work is only a satisfier group

2) Motivation factors (Motivation factors): Motivators or Satisfiers are factors or situations that are proven to be sources of job satisfaction which consist of interesting work full of challenges, opportunities for achievement, opportunities to get awards, and promotions. The fulfillment of these factors will lead to satisfaction, but the non-fulfillment of these factors does not always lead to satisfaction.

According to Sutrisno (2016, as cited in Lusri \& Siagian, 2017) the factors that affect job satisfaction, namely:

1. Psychological factors, are factors related to the employee's psyche, including interest, peace in work and attitudes towards work.

2. Social factors, are factors related to social interaction between employees and employees with superiors.

3. Physical factors are factors related to the physical condition of employees at work, including the type of work, working time and rest time arrangements, work equipment, and the physical condition of the workplace.

4. Financial factors, are factors related to employee security and welfare, which include the system and the amount of salary, social security and promotion opportunities.

\subsubsection{Organizational culture}

According to Robbins, organizational culture is a shared perception held by members of the organization. A habit that has lasted a long time and is used and applied in the life of work activities as one of the drivers to improve the quality of work of employees (Ikhsan, 2016). Thus, it can be concluded that organizational culture is a pattern of organizational beliefs and values that must be owned by all employees in doing their jobs properly. The indicators of organizational culture according to Robbins (2003, as cited in Ikhsan, 2016) are:

a) Innovation and risk taking, which is related to the extent to which organizational members or employees are encouraged to be innovative and dare to take risks.

b) Attention to detail (attention to details), which relates to the extent to which members of the organization or employees are expected to show accuracy, analysis and attention to details (details).

c) Outcome orientation, namely the extent to which management focuses on results, not on the techniques and processes used to obtain those results.

d) People Orientation (individual orientation), namely the extent to which management decisions take into account the effect of outcomes on people within the organization.

e) Team Orientation, which is related to the extent to which organizational work activities are carried out in work teams, not individuals.

f) Aggressiveness (aggressiveness), namely the extent to which people in the organization show aggressiveness and competitiveness, rather than relaxing.

g) Stability (stability), namely the extent to which organizational activities emphasize maintaining the status quo as opposed to growth or innovation.

\subsubsection{Servant Leadership}

Servant leadership according to (Sendjaya et al., 2008) is a leader who prioritizes interests, needs, aspirations and is committed to serving others. The idea of servant leadership leads to behavior that fosters and gives advice to 
coworkers. Leaders who pay attention to the humanistic aspect who seek to build good relations by developing enthusiasm and selflessness. According to (Sendjaya et al., 2008) servant leadership is a leader who focuses on employees and their aspirations are very important compared to organizational goals. While transformational, the leader will empower and inspire employees to act beyond what the leader expects, and is related to the company's goals in terms of company development.

\subsubsection{Self Leadership}

Self-leadership or what can be called self-leadership is essentially the ability to increase individual effectiveness through three strategies, namely: behavioral focus strategies, natural reward strategies, and constructive thinking. Behavioral focus strategies consist of self-observation, self-goal setting, self-reward, selfpunishment, and self-criticism and advice. Natural rewards are giving rewards to oneself to feel satisfied with what has been done, while the constructive thinking strategy consists of beliefs and assumptions, self-talk, and self-image (Sarmawa et al., 2017). Employees have expectations regarding their performance and their positive or negative reactions in response to their own evaluations. Organizational efforts on employee control do not recognize the importance of the role of the so-called "self" (Sawitri et al., 2018).

\subsubsection{Compensation}

According to (Purnama \& Kempa, 2016) compensation has two forms, namely financial and non-financial compensation. Financial compensation consists of direct compensation and indirect compensation. Direct financial compensation consists of salaries or wages while indirect financial compensation consists of allowances and facilities. And non-financial compensation consists of praise and promotion.

\subsubsection{Employee performance}

Performance can affect the ongoing activities of a company organization, the better the performance shown by employees will be very helpful in the development of the organization or company (Lusri \& Siagian, 2017). According to Suwondo and Sutanto (2015, as cited in Lusri \& Siagian, 2017) states that to facilitate employee performance appraisal, the standards that must be measured and understood are as follows:

a) Accuracy in completing work (work results), namely accuracy in completing work, attention to quality in completing work, ability to meet company targets and ability to complete work on time.

b) The level of initiative in work, including the ability to anticipate problems that may occur and the ability to create alternative solutions to these problems.

c) Mental dexterity, mental dexterity is measured through the ability of employees to understand the directions given by the leader and the ability of employees to cooperate with other co-workers.

d) Discipline of time and attendance, is the level of punctuality and level of attendance of employees at work.

\section{Research Methods}

\subsection{Analysis Model}

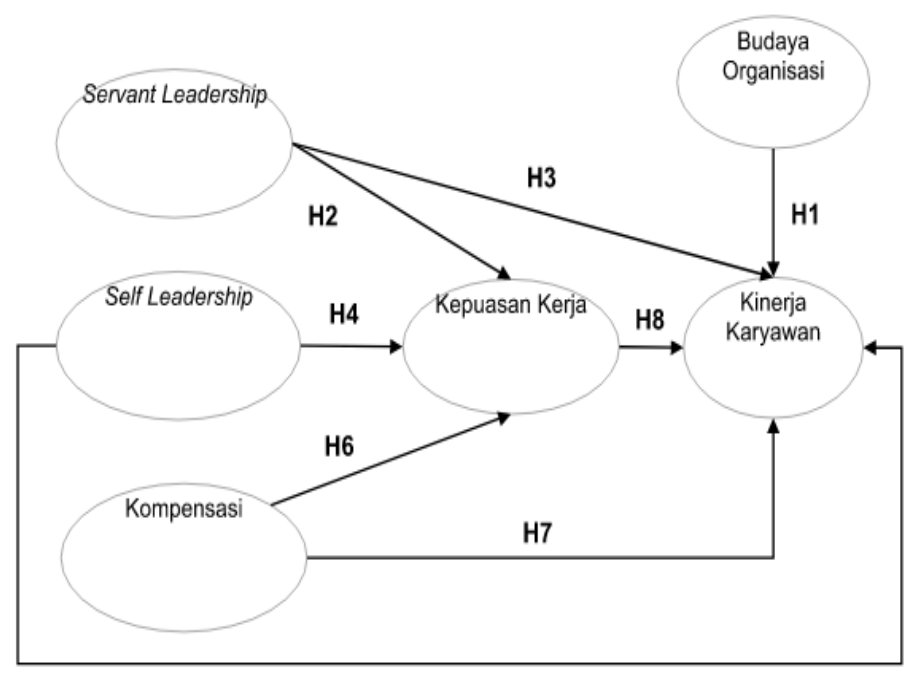


Figure 3.1. Hypothesis Framework

In this study, there are 4 independent variables, namely Organizational Culture (X1), Servant Leadership (X2), Self Leadership (X3), Compensation (X4) and 2 intermediary variables, namely Job Satisfaction (Y1), Employee Performance (Y2).

Hypothesis;

H1: Organizational culture affects the performance of CV Inti Computer employees in Kediri.

H2: Servant Leadership has an effect on job satisfaction of CV Inti Computer employees in Kediri.

H3: Servant Leadership affects the performance of CV Inti Computer employees in Kediri.

H4: Self Leadership has an effect on job satisfaction of CV Inti Computer employees in Kediri.

H5: Self Leadership affects the performance of CV Inti Computer employees in Kediri.

H6: Compensation affects job satisfaction of CV Inti Computer employees in Kediri.

H7: Compensation affects the performance of CV Inti Computer employees in Kediri.

H8: Job satisfaction affects the performance of CV Inti Computer employees in Kediri.

\subsection{Research Approach}

This research is an explanatory research that will prove a causal relationship between the independent variables (exogenous variables), namely organizational culture, servant leadership, self leadership, and compensation; and the dependent variable (indogen variable), namely job satisfaction and employee performance. This study uses statistical data analysis techniques Partial Least Square (PLS) which can be used to analyze Structural Equation Modeling (SEM). The population in this study were all employees of CV Inti Computer Kediri, totaling 30 employees. In this study, researchers used a population of all employees, amounting to 30 people.

\subsection{Method of collecting data}

\subsubsection{Data source}

This study uses data obtained through respondents, where respondents will provide verbal responses and or written responses in response to the statements given. In this study, secondary data only supports the initial data collection as research output. That is in the form of interviews. This study uses a measurement scale used is a Likert scale. To determine the number of samples can use the Slovin formula as follows:

$$
N=\frac{N}{1+N e^{2}}
$$

Description :

$\mathrm{n}=$ Sample Size

$\mathrm{N}=$ Population Size

$\mathrm{e}=$ Estimated Error

The scale used is:

1. Strongly Agree with a score of 5 with a range (4.21-5.00)

2. Agree with a score of 4 with a range $(3,41-4,20)$

3. Simply Agree with a score of 3 with a range (2.61-3.40)

4. Disagree with a score of 2 with a range (1.81-2.60)

5. Strongly Disagree with a score of 1 with a range (1.00-1.80)

\section{Result and Discussion}

\subsection{Respondents Descriptive Analysis}

The majority of respondents in this study were 16 female respondents, while the remaining 14 male respondents were. Most of the respondents in this study were aged 25-30 years with a total of 16 respondents, and those aged less than $<25$ years were 12 people, while those aged $>40$ years were 2 people. The majority of respondents worked for less than 5 years as many as 28 people, while the rest had 2 years of work for more than 5 years. The table above shows that employees with a tenure of more than 5 years have more experience and maturity than those with less than 5 years, so that the employee understands what to do at work. The position or position of the respondents in this study were programmers as many as 21 people. While the positions or positions of staff are 9 people. This shows that employees whose positions or positions are programmers are more likely to be researched. The majority of respondents' monthly expenses in this study were less than $<500000$ as many as 28 
people. Meanwhile, there are 2 people who have monthly expenses of more than 500000 . The status of the respondents in this study was married as many as 6 people. While those who are not married are 24 people. This shows that most of the employees in this company are still not married.

\subsection{Data Analysis with Smart-PLS}

\subsubsection{Structural Model}

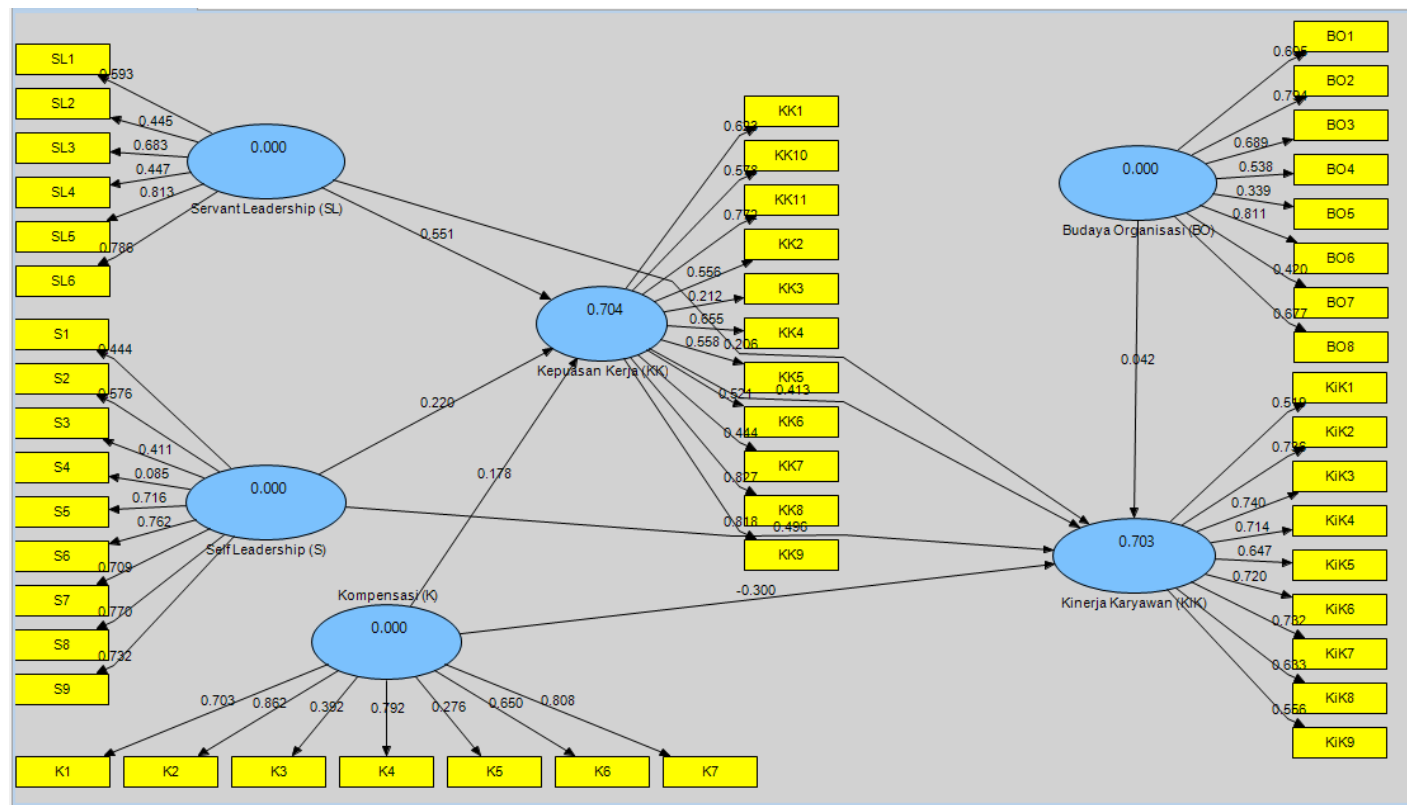

Figure 4.1. Structural Model 1

Based on the results of running data on the model, there are several items that must be deleted because they do not meet the cut off of the loading factor, namely SL2, SL4, S1, S3, S4, K3, K5, KK3, KK6, KK7, KK9, B04, B05, B06, and B07.

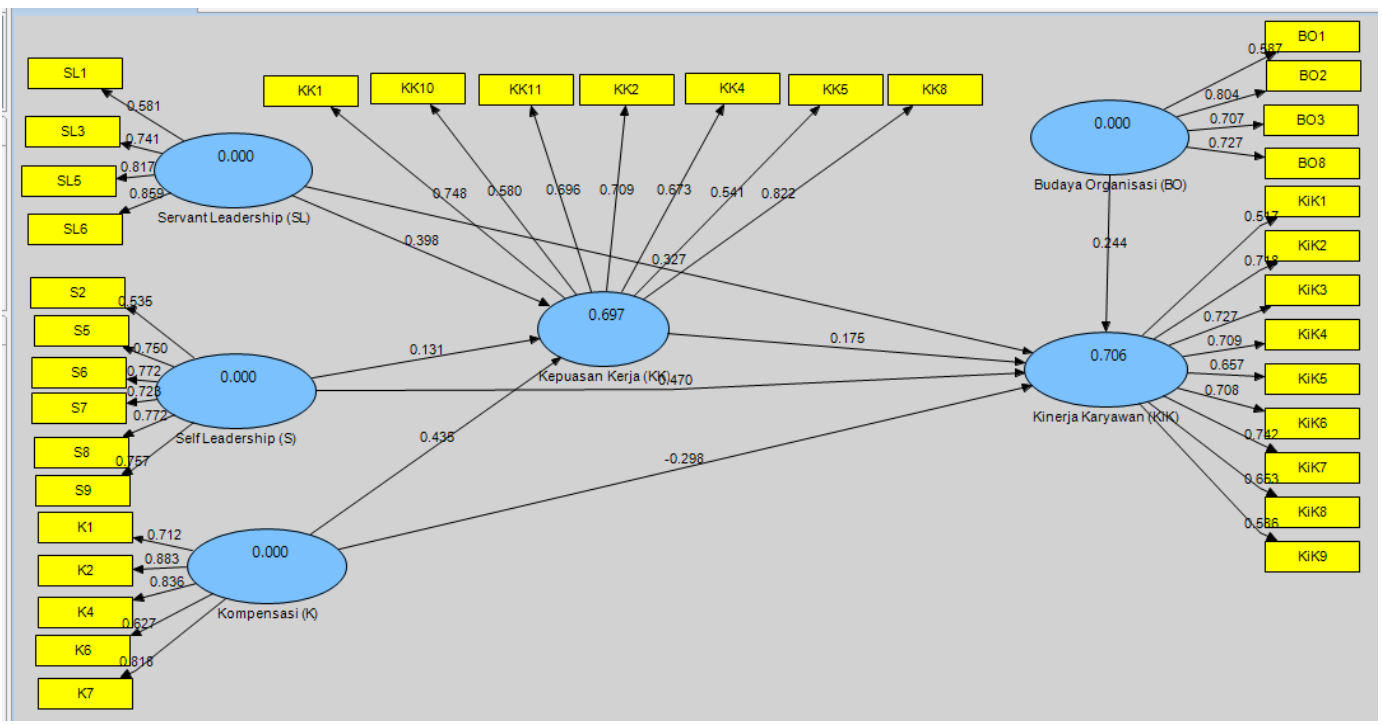

\subsubsection{Outer Model Evaluation}

Figure 4.2. Structural Model 2

Convergent validity of the measurement model with reflexive indicators is assessed based on the correlation between the estimated item scores with PLS software. According to (1998, as cited in Ghozali, 2006) for research in the early stages of developing a measurement scale, the loading value of 0.5 to 0.6 is considered sufficient.

a. Validity test

Table 4.1. Loading Factor

\begin{tabular}{|c|c|c|c|c|c|c|}
\hline Var & $\begin{array}{c}\text { Organizational } \\
\text { Culture (BO) }\end{array}$ & $\begin{array}{c}\text { Compensation } \\
(\text { K) }\end{array}$ & $\begin{array}{c}\text { Job } \\
\text { Satisfaction } \\
\text { (KK) }\end{array}$ & $\begin{array}{c}\text { Employee } \\
\text { Performance } \\
\text { (KiK) }\end{array}$ & $\begin{array}{c}\text { Self Leadership } \\
\text { (S) }\end{array}$ & $\begin{array}{c}\text { Servant } \\
\text { Leadership (SL) }\end{array}$ \\
\hline BO1 & 0.586595 & & & & & \\
\hline
\end{tabular}




\begin{tabular}{|c|c|c|c|c|c|c|}
\hline BO2 & 0.804431 & & & & & \\
\hline BO3 & 0.707250 & & & & & \\
\hline BO8 & 0.726543 & & & & & \\
\hline K1 & & 0.712047 & & & & \\
\hline $\mathbf{K} 2$ & & 0.882511 & & & & \\
\hline K4 & & 0.835526 & & & & \\
\hline K6 & & 0.627084 & & & & \\
\hline K7 & & 0.817591 & & & & \\
\hline KK1 & & 0.712047 & & & & \\
\hline KK10 & & & 0.579990 & & & \\
\hline KK11 & & & 0.696368 & & & \\
\hline KK2 & & & 0.709377 & & & \\
\hline KK4 & & & 0.672725 & & & \\
\hline KK5 & & & 0.541139 & & & \\
\hline KK8 & & & 0.822229 & & & \\
\hline KiK1 & & & & 0.517254 & & \\
\hline KiK2 & & & & 0.718413 & & \\
\hline KiK3 & & & & 0.726840 & & \\
\hline KiK4 & & & & 0.709136 & & \\
\hline KiK5 & & & & 0.657400 & & \\
\hline KiK6 & & & & 0.707765 & & \\
\hline KiK7 & & & & 0.742363 & & \\
\hline KiK8 & & & & 0.652774 & & \\
\hline KiK9 & & & & 0.585689 & & \\
\hline S2 & & & & & 0.534839 & \\
\hline S5 & & & & & 0.749505 & \\
\hline S6 & & & & & 0.771555 & \\
\hline S7 & & & & & 0.723164 & \\
\hline S8 & & & & & 0.771718 & \\
\hline S9 & & & & & 0.756500 & \\
\hline SL1 & & & & & & 0.580598 \\
\hline SL3 & & & & & & 0.740910 \\
\hline SL5 & & & & & & 0.816857 \\
\hline SL6 & & & & & & 0.859310 \\
\hline
\end{tabular}

The table above shows that the loading factor gives a value above the recommended value of 0.5 . The smallest value is 0.517254 for the KiK1 indicator. It means that the indicators used in this study are valid or have met convergent validity. 


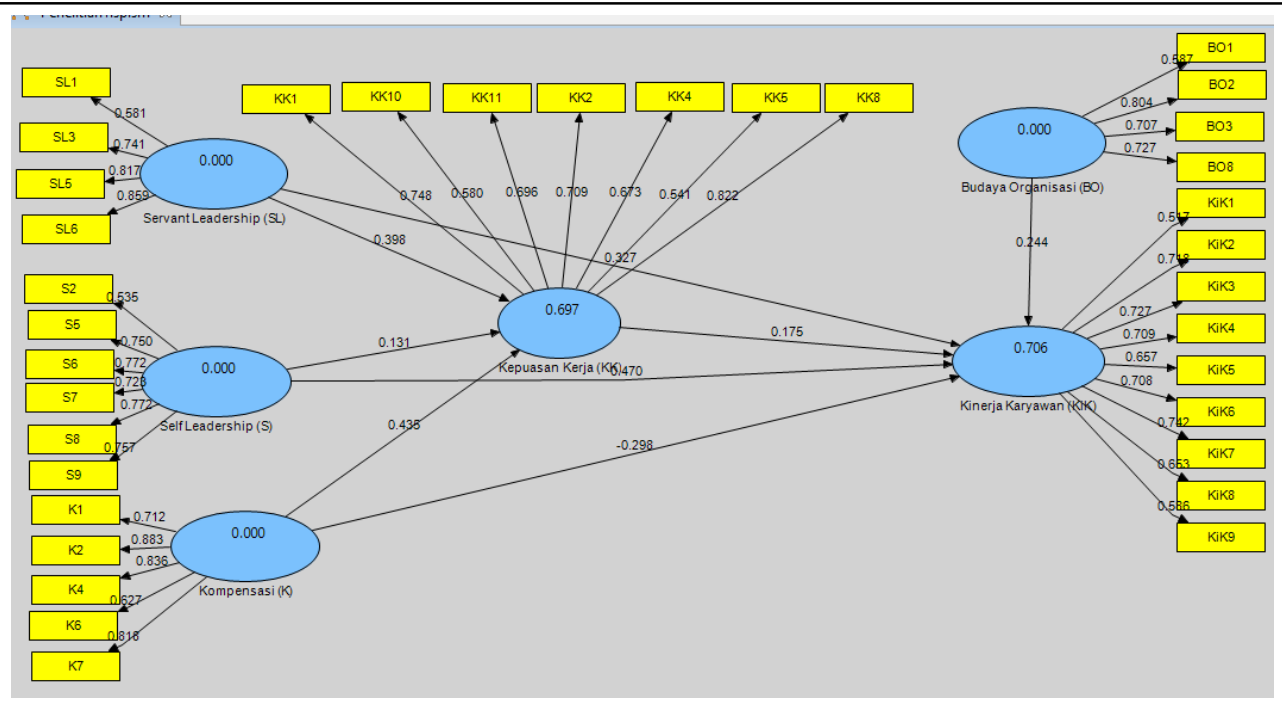

Figure 4.3. Load Factor Value

The reflective indicators in this test also need to be tested using discriminant validity with cross loading shown in the table as follows:

Tabel 4.2. Cross Loading

\begin{tabular}{|c|c|c|c|c|c|c|}
\hline & $\begin{array}{c}\text { Organizational } \\
\text { Culture (BO) }\end{array}$ & $\begin{array}{c}\text { Compensation } \\
\text { (K) }\end{array}$ & $\begin{array}{c}\text { Job Satisfaction } \\
\text { (KK) }\end{array}$ & $\begin{array}{c}\text { Employee } \\
\text { Performance } \\
\text { (KiK) }\end{array}$ & $\begin{array}{l}\text { Self Leadership } \\
\text { (S) }\end{array}$ & $\begin{array}{l}\text { Servant Leadership } \\
\text { (SL) }\end{array}$ \\
\hline BO1 & 0.586595 & 0.406945 & 0.266845 & 0.106878 & 0.469637 & 0.083582 \\
\hline BO2 & 0.804431 & 0.556625 & 0.536146 & 0.584755 & 0.674213 & 0.455548 \\
\hline BO3 & 0.707250 & 0.365943 & 0.410968 & 0.337761 & 0.424508 & 0.234985 \\
\hline BO8 & 0.726543 & 0.221729 & 0.372803 & 0.541077 & 0.360139 & 0.311271 \\
\hline K1 & 0.238579 & 0.712047 & 0.580813 & 0.415851 & 0.381117 & 0.600004 \\
\hline K2 & 0.571638 & 0.882511 & 0.635466 & 0.320741 & 0.514758 & 0.515632 \\
\hline K4 & 0.591654 & 0.835526 & 0.540613 & 0.281439 & 0.362507 & 0.452850 \\
\hline K6 & 0.117375 & 0.627084 & 0.560105 & 0.188059 & 0.254178 & 0.534996 \\
\hline K7 & 0.503532 & 0.817591 & 0.601774 & 0.325998 & 0.366274 & 0.371578 \\
\hline KK1 & 0.341514 & 0.600052 & 0.748356 & 0.299365 & 0.287830 & 0.620644 \\
\hline KK10 & 0.351708 & 0.529344 & 0.579990 & 0.159789 & 0.149026 & 0.446190 \\
\hline KK11 & 0.407937 & 0.361789 & 0.696368 & 0.551297 & 0.302762 & 0.565232 \\
\hline KK2 & 0.206904 & 0.650908 & 0.709377 & 0.149472 & 0.287290 & 0.554696 \\
\hline KK4 & 0.179928 & 0.343717 & 0.672725 & 0.566253 & 0.460127 & 0.517802 \\
\hline KK5 & 0.512996 & 0.258156 & 0.541139 & 0.307028 & 0.399326 & 0.211398 \\
\hline KK8 & 0.718932 & 0.649066 & 0.822229 & 0.663638 & 0.670901 & 0.572300 \\
\hline KiK1 & 0.469600 & 0.155993 & 0.324588 & 0.517254 & 0.445841 & 0.212674 \\
\hline KiK2 & 0.504779 & 0.361754 & 0.605992 & 0.718413 & 0.595803 & 0.430119 \\
\hline KiK3 & 0.470097 & 0.368902 & 0.468206 & 0.726840 & 0.496809 & 0.371854 \\
\hline KiK4 & 0.408417 & 0.412679 & 0.626676 & 0.709136 & 0.510452 & 0.618428 \\
\hline KiK5 & 0.378382 & 0.285940 & 0.399294 & 0.657400 & 0.493168 & 0.587864 \\
\hline KiK6 & 0.407498 & 0.182684 & 0.369179 & 0.707765 & 0.594813 & 0.510164 \\
\hline KiK7 & 0.323837 & 0.133509 & 0.303538 & 0.742363 & 0.453064 & 0.306744 \\
\hline KiK8 & 0.395098 & 0.047082 & 0.041305 & 0.652774 & 0.343555 & 0.208985 \\
\hline
\end{tabular}




\begin{tabular}{|c|c|c|c|c|c|c|}
\hline KiK9 & 0.577948 & 0.375951 & 0.281491 & 0.585689 & 0.455861 \\
\hline S2 & 0.174939 & 0.100569 & 0.215913 & 0.283085 & 0.534839 \\
\hline S5 & 0.425525 & 0.304496 & 0.252351 & 0.537031 & 0.749505 \\
\hline S6 & 0.615430 & 0.220156 & 0.312382 & 0.586329 & 0.771555 \\
\hline S7 & 0.394403 & 0.170097 & 0.375523 & 0.627006 & 0.723164 \\
\hline S8 & 0.667083 & 0.668199 & 0.586581 & 0.541292 & 0.771718 \\
\hline S9 & 0.504867 & 0.496637 & 0.536252 & 0.620483 & 0.756500 \\
\hline SL1 & 0.196273 & 0.172227 & 0.422561 & 0.214098 & 0.433245 \\
\hline SL3 & 0.396701 & 0.572873 & 0.640971 & 0.511885 & 0.047538 \\
\hline SL5 & 0.490790 & 0.659439 & 0.616542 & 0.476734 & 0.500604 \\
\hline SL6 & 0.238383 & 0.422988 & 0.546898 & 0.607907 & 0.507985 \\
\hline
\end{tabular}

Source: primary data processed (2019).

Thus, latent contracts predict indicators in their block better than indicators in other blocks. Another method to see discriminant validity is to look at the value of the square root of average variance extracted (AVE).

Table 4.3. Average Variance Extracted (AVE)

\begin{tabular}{|c|c|}
\hline Variable & AVE \\
\hline Organizational Culture (BO) & 0.504817 \\
\hline Job Satisfaction (KK) & 0.572289 \\
\hline Employee Performance (KiK) & 0.552021 \\
\hline Compensation (K) & 0.609125 \\
\hline Self Leadership (S) & 0.522319 \\
\hline Servant Leadership (SL) & 0.572928 \\
\hline
\end{tabular}

Source: primary data processed (2019).

Based on the results of the table above, the AVE value is above 0.5 for all constructs contained in the research model. The lowest value of AVE is 0.504817 in the BO construct (Organizational Culture).

b. Reliability Test

Table 4.4. Composite Reliability

\begin{tabular}{|c|c|c|}
\hline Variable & Composite Reliability & Model Evaluation \\
\hline Organizational Culture (BO) & 0.801138 & reliable \\
\hline Job Satisfaction (KK) & 0.860334 & reliable \\
\hline Employee Performance (KiK) & 0.880132 & reliable \\
\hline Compensation (K) & 0.884821 & reliable \\
\hline Self Leadership (S) & 0.866188 & reliable \\
\hline Servant Leadership (SL) & 0.840262 & reliable \\
\hline
\end{tabular}

Source: primary data processed (2019).

The table above shows that the composite reliability value for all constructs is above 0.7 which indicates that all constructs in the estimated model meet the discriminant validity criteria. The lowest composite reliability value is 0.801138 in the $\mathrm{BO}$ construct (Organizational Culture).

Table 4.5. Cronbach Alpha

\begin{tabular}{|c|c|c|}
\hline Variable & Cronbachs Alpha & Model Evaluation \\
\hline Organizational Culture (BO) & 0.703501 & reliable \\
\hline Job Satisfaction (KK) & 0.812114 & reliable \\
\hline Employee Performance (KiK) & 0.847175 & reliable \\
\hline Compensation (K) & 0.834163 & reliable \\
\hline Self Leadership (S) & 0.815777 & reliable \\
\hline Servant Leadership (SL) & 0.747669 & reliable \\
\hline
\end{tabular}


Based on the table above, it shows that the Cronbach's Alpha value for all constructs is above 0.6. The lowest value is $0.703501(\mathrm{BO})$.

\subsection{Inner Model Evaluation}

Testing the estimated model that the test meets the Outer Model criteria, then the structural model test (Inner model) must then be tested.

Table 4.6. R-Square Value

\begin{tabular}{|c|c|}
\hline Variable & R-Square Value \\
\hline Organizational Culture (BO) & - \\
\hline Job Satisfaction (KK) & 0.696554 \\
\hline Employee Performance (KiK) & 0.705879 \\
\hline Compensation (K) & - \\
\hline Self Leadership (S) & - \\
\hline Servant Leadership (SL) \\
\hline \multicolumn{2}{|c|}{ Source: primary data processed (2019). } \\
\hline
\end{tabular}

The table above gives a value of 0.696554 for the KiK construct which means that SL, S, K affect KiK by $69.65 \%$. The Rsquare value is also found in KiK which is influenced by KK, K, S, SL and BO, which is 0.705879 which means that performance is influenced by $\mathrm{KK}, \mathrm{K}, \mathrm{S}, \mathrm{SL}$, and BO by $70.5 \%$.

\subsection{Hypothesis test}

The hypothesis is based on the value contained in the structural analysis model, the path coefficient significance level is obtained from the t-statistic value and the standard path coefficient value. The limit value of hypothesis testing is $\mathrm{t}$ loading factor.

Tabel 4.7. Path Coefficient Hypothesis Testing (Mean, STDEV, T-Values)

\begin{tabular}{|l|c|c|c|c|c|l|}
\hline \multicolumn{1}{|c|}{ Variable } & $\begin{array}{c}\text { Original } \\
\text { Sample (O) }\end{array}$ & $\begin{array}{c}\text { Sample Mean } \\
\text { (M) }\end{array}$ & $\begin{array}{c}\text { Standard } \\
\text { Deviation } \\
\text { (STDEV) }\end{array}$ & $\begin{array}{c}\text { Standard Error } \\
\text { (STERR) }\end{array}$ & $\begin{array}{c}\text { T Statistics } \\
(\text { |O/STERR|) }\end{array}$ & \multicolumn{1}{c|}{ Description } \\
\hline $\begin{array}{l}\text { Organizational Culture } \\
\text { (BO) -> Employee } \\
\text { Performance (KiK) }\end{array}$ & 0.2442 & 0.3135 & 0.1738 & 0.1738 & 1.4050 & $\begin{array}{l}\text { Not } \\
\text { significant }\end{array}$ \\
\hline $\begin{array}{l}\text { Job Satisfaction (KK) -> } \\
\text { Employee Performance } \\
\text { (KiK) }\end{array}$ & 0.1749 & 0.1023 & 0.3034 & 0.3034 & 0.5764 & $\begin{array}{l}\text { Not } \\
\text { significant }\end{array}$ \\
\hline $\begin{array}{l}\text { Compensation (K) -> } \\
\text { Job Satisfaction (KK) }\end{array}$ & 0.4346 & 0.4254 & 0.1952 & 0.1952 & 2.2267 & Significant \\
\hline $\begin{array}{l}\text { Compensation (K) -> } \\
\text { Employee Performance } \\
\text { (KiK) }\end{array}$ & -0.2982 & -0.2477 & 0.2387 & 0.2387 & 1.2490 & $\begin{array}{l}\text { Not } \\
\text { significant }\end{array}$ \\
\hline $\begin{array}{l}\text { Self Leadership (S) -> } \\
\text { Job Satisfaction (KK) }\end{array}$ & 0.1315 & 0.1407 & 0.1625 & 0.1625 & 0.8091 & $\begin{array}{l}\text { Not } \\
\text { significant }\end{array}$ \\
\hline $\begin{array}{l}\text { Self Leadership (S) -> } \\
\text { Employee Performance } \\
\text { (KiK) }\end{array}$ & 0.4698 & 0.4431 & 0.1734 & 0.1734 & 2.7101 & Significant \\
\hline $\begin{array}{l}\text { Servant Leadership (SL) } \\
\text { - Job Satisfaction (KK) }\end{array}$ & 0.3983 & 0.3791 & 0.2021 & 0.2021 & 1.9705 & $\begin{array}{l}\text { Not } \\
\text { significant }\end{array}$ \\
\hline $\begin{array}{l}\text { Servant Leadership (SL) } \\
\text { - Employee } \\
\text { Performance (KiK) }\end{array}$ & 0.3274 & 0.3234 & 0.2092 & 0.2092 & 1.5645 & Not \\
\hline
\end{tabular}

Source: primary data processed (2019).

The results of the relationship between latent variables can be concluded as follows:

a) The Influence of Organizational Culture on Employee Performance

Testing the relationship between the second variable from the path coefficient model in this study found that the original sample value of the organizational culture variable on employee performance was 0.2442 and the t-count value was 1.4050. This shows that the original sample estimate value of organizational culture is positive, namely 0.2442 which indicates that the direction of the relationship between Organizational Culture and Employee Performance is positive. 
b) The Influence of Servant Leadership on Job Satisfaction

Testing the relationship between the second variable from the path coefficient model in this study found that the original sample value of the Servant Leadership variable on Job Satisfaction was 0.3983 and the t-count value was 1.9705. This shows that the value of the original sample estimate of Servant Leadership is positive, which is 0.3983 which indicates that the direction of the relationship between Servant Leadership and Job Satisfaction is positive.

c) The Influence of Servant Leadership on Employee Performance

Testing the relationship between the second variable from the path coefficient model in this study found that the original sample value of the Servant Leadership variable on Employee Performance was 0.3274 and the t-count value was 1.5645 . It shows that the value of the original sample estimate Servant Leadership is positive in the amount of 0.3274 which indicates that the direction of the relationship between Servant Leadership with Employee Performance was positive.

d) The Influence of Self Leadership on Job Satisfaction.

Testing the relationship between the second variable from the path coefficient model in this study found that the original sample value of the Self Leadership variable on Job Satisfaction was 0.1315 and the $\mathrm{t}$-count value was 0.8091 . This shows that the value of the original sample estimate of Self Leadership is positive, which is 0.1315 which indicates that the direction of the relationship between Self Leadership and Job Satisfaction is positive.

e) The Influence of Self Leadership on Employee Performance.

Testing the relationship between the second variable from the path coefficient model in this study found that the original sample value of the Self Leadership variable on Employee Performance was 0.4698 and the t-count value was 2.7101. This shows that the value of the original sample estimate of Self Leadership is positive, which is 0.4698 which indicates that the direction of the relationship between Self Leadership and Employee Performance is positive.

f) Effect of Compensation on Job Satisfaction.

Testing the relationship between the second variable from the path coefficient model in this study found that the original sample value of the Compensation to Job Satisfaction variable was 0.4346 and the tcount value was 2.2267. Page 88 shows that the value of the original sample estimate of Compensation is positive, which is 0.4346 which indicates that the direction of the relationship between Compensation and Job Satisfaction is positive.

g) The Influence of Compensation on Employee Performance

Testing the relationship between the second variable from the path coefficient model in this study found that the original sample value of the Compensation for Employee Performance variable was - 0.2982 and the t-count value of 1.2490 showed that the original sample estimate Compensation value was positive, namely -0.2982 which indicates that the direction of the relationship between compensation and employee performance is positive.

h) The Influence of Job Satisfaction on Employee Performance.

Testing the relationship between the second variable from the path coefficient model in this study found that the original sample value of the Job Satisfaction variable on Employee Performance was 0.1749 and the t-count value was 0.5764 . This shows that the original sample estimate of Job Satisfaction is positive, which is 0.1749 which indicates that the direction of the relationship between Job Satisfaction and Employee Performance is positive.

\section{Conclusions and Practical Implication}

\subsection{Conclusion}

Organization (X1) has no significant effect on employee performance. So that the first hypothesis (H1) is not accepted because the results obtained are not in accordance with the hypothesis. Servant Leadership (X2) has no significant effect on job satisfaction. So that the second hypothesis (H2) is not accepted because the results obtained are not in accordance with the hypothesis. Servant Leadership (X3) has no significant effect on employee 
performance. So the third hypothesis (H3) is not accepted because the results obtained are not in accordance with the hypothesis. Self Leadership (X4) has no significant effect on job satisfaction. So that the fourth hypothesis (H4) is not accepted because the results obtained are not in accordance with the hypothesis. Self Leadership (X5) has a significant effect on employee performance. So that the fifth hypothesis (H5) is accepted because the results obtained are in accordance with the hypothesis. Compensation (X6) has a significant effect on job satisfaction. So the sixth hypothesis (H6) is accepted because the results obtained are in accordance with the hypothesis. Compensation (X7) has no significant effect on employee performance. So the seventh hypothesis (H7) is not accepted because the results obtained are not in accordance with the hypothesis. Job Satisfaction (Y1) has no significant effect on employee performance. So the eighth hypothesis (H8) is not accepted because the results obtained are not in accordance with the hypothesis.

\subsection{Practical Implication}

Table 5.1. Managerial Implications

\begin{tabular}{|c|c|c|c|}
\hline No. & Variable & Before Research & After Research \\
\hline 1. & Job satisfaction & $\begin{array}{l}\text { - There has been no promotion for each } \\
\text { employee. } \\
\text { - The work atmosphere is not } \\
\text { conducive. }\end{array}$ & $\begin{array}{l}\text { - There is a promotion when there are } \\
\text { competent employees. } \\
\text { - Get a conducive atmosphere for employees to } \\
\text { avoid boredom at work. }\end{array}$ \\
\hline 2. & $\begin{array}{l}\text { Organizational } \\
\text { culture }\end{array}$ & $\begin{array}{l}\text { - An organizational culture has not yet } \\
\text { been formed to improve employee } \\
\text { welfare. }\end{array}$ & $\begin{array}{l}\text { - The creation of a corporate organizational } \\
\text { culture so that employees feel comfortable in } \\
\text { their work. }\end{array}$ \\
\hline 3. & $\begin{array}{l}\text { Servant } \\
\text { Leadership }\end{array}$ & $\begin{array}{l}\text { - There are no employees who can } \\
\text { protect each other and humbly help } \\
\text { their co-workers in their work. }\end{array}$ & $\begin{array}{l}\text { - Creating employees who try to accept, } \\
\text { understand and provide empathy for co- } \\
\text { workers. }\end{array}$ \\
\hline 4. & Self-Leadership & $\begin{array}{l}\text { - Employees who are difficult to be } \\
\text { independent and must always be } \\
\text { directed in doing their work. }\end{array}$ & $\begin{array}{l}\text { - Have employees who can be independent and } \\
\text { have creative ideas. }\end{array}$ \\
\hline 5. & Compensation & $\begin{array}{l}\text { - The value of the basic salary is in } \\
\text { accordance with the ability and work } \\
\text { responsibilities of the employee. } \\
\text { Provide benefits to each employee. }\end{array}$ & $\begin{array}{l}\text { - Increasing the basic salary is made based on a } \\
\text { point system, so that each employee can know } \\
\text { the basic amount of the basic salary they } \\
\text { receive. } \\
\text { - If the employee can achieve a target, other } \\
\text { benefits will be given. }\end{array}$ \\
\hline 6. & $\begin{array}{l}\text { Employee } \\
\text { performance }\end{array}$ & $\begin{array}{l}\text { - Improvement of employee } \\
\text { performance evaluation so that } \\
\text { individual performance can be } \\
\text { evaluated appropriately. }\end{array}$ & $\begin{array}{l}\text { - Employees are motivated to improve } \\
\text { performance because the process is transparent } \\
\text { and feels "fair". Appropriate performance } \\
\text { appraisal will help management to get } \\
\text { the best talent for the company. }\end{array}$ \\
\hline
\end{tabular}

Source: processed by researchers (2019)

\section{References}

Andriani, M., \& Widiawati, K. (2017). Penerapan motivasi karyawan menurut teori dua faktor frederick herzberg pada PT Aristika Kreasi Mandiri. Jurnal Administrasi Kantor, 5(1), 83-98.

Changgriawan, G. S. (2017). Pengaruh kepuasan kerja dan motivasi kerja terhadap kinerja karyawan di One Way Production. Agora, 5(2), 1-7.

Ghozali, I. (2006). Structurar equation modeling, metode alternatif dengan partial least square. Semarang: Badan Penerbit Universitas Diponegoro.

Herzberg, F. (1959). Mausner B., and Snyderman B. The Motivation to Work. New York: Wiley.

Husein, M. A., Indupurnahayu, I., \& Rahim, A. (2018). Gaya kepemimpinan, budaya organisasi dan motivasi terhadap prestasi santri (Studi kasus di Pesantren Terpadu Daaruttaqwa Cibinong Bogor Jawa Barat). Jurnal Manajemen, 9(1), 30-36. https://doi.org/10.32832/jm-uika.v9i1.1286

Ikhsan, A. (2016). Analisis pengaruh budaya organisasi dan kepuasan kerja terhadap kinerja karyawan non dosen pada Universitas Mercu Buana Jakarta. Jurnal Ilmiah Manajemen Dan Bisnis Mercu Buana, 2(1), 438-456. https://doi.org/http://dx.doi.org/10.22441/jimb.v2i1.3688

Lusri, L., \& Siagian, H. (2017). Pengaruh motivasi kerja terhadap kinerja karyawan melalui kepuasan kerja 
sebagai variabel mediasi pada karyawan PT. Borwita Citra Prima Surabaya. Agora, 5(1), 1-8.

Noor, M. S. A., Wahyudin, W., \& Riyadi, M. (2018). Implementasi rencana strategis pelayanan keperawatan dalam perspektif kepemimpinan kepala ruangan berbasis budaya organisasi di Rumah Swasta. CNJ: Caring Nursing Journal, 2(2), 51-59. https://journal.umbjm.ac.id/index.php/caringnursing/article/view/192

Purnama, C., \& Kempa, S. (2016). Pengaruh kompensasi dan disiplin kerja terhadap kinerja karyawan CV. Cahaya Citrasurya Indoprima. Agora, 4(2), 33-39.

Sarmawa, I. W. G., Suparta, I. W. G., Riana, I. G., \& Dewi, I. G. A. M. (2017). Influence of self-leadership on employee performance with work culture as mediator: Study at Tenun Ikat industries in Klungkung-Bali, Indonesia. International Journal of Economics, Commerce and Management, V(12).

Sawitri, D., Cahyandari, N., \& Muawanah, U. (2018). Hubungan self leadership, self efficacy dan kecerdasan intelektual terhadap kinerja karyawan pada Badan Pendapatan Daerah Kabupaten Mojokerto. Jurnal Manajemen Dan Bisnis Indonesia, 6(1), 76-90. https://doi.org/10.31843/jmbi.v6i1.184

Sendjaya, S., Sarros, J. C., \& Santora, J. C. (2008). Defining and measuring servant leadership behaviour in organizations. Journal of Management Studies, 45(2), 402-424. https://doi.org/10.1111/j.14676486.2007.00761.x

Veriyani, R., \& Prasetio, A. P. (2018). Pengaruh kompensasi terhadap kepuasan kerja karyawan pada divisi produksi PT. Soljer Abadi. Jurnal Ilmiah Manajemen, Ekonomi, \& Akuntansi (MEA), 2(2), 1-14. https://doi.org/10.31955/jimea.vol2.iss2.pp1-14

Warrick, D. D. (2017). What leaders need to know about organizational culture. Business Horizons, 60(3), 395-404. https://doi.org/10.1016/j.bushor.2017.01.011

Ziyae, B., \& Heydari, R. (2016). Investigating the effect of self-leadership on entrepreneurs' innovation in small and medium-sized enterprises. International Journal of Humanities and Cultural Studies (IJHCS) ISSN 2356-5926, 2(4), 1169-1182. 